\title{
Antinutrient contents of watermelon seeds
}

\begin{abstract}
Watermelon (Citrullus lanatus) seeds are often discarded while the fruit is eaten. However, previous studies have shown watermelon seeds as considerable source of food for human nutrition and health. In the present study, seeds of three (3) varieties of watermelons (Kaolak, Crimson sweet and Sugar baby) were analysed for their moisture content and antinutrients; oxalate, phytate and tannin levels. The oxalate, phytate and tannin contents were determined by means of potassium permanganate titration method, Iron (I) chloride titration method and Folin-Ciocalteau assay, respectively. The seeds were also boiled-oven dried and roasted to determine the effects of the processing on the antinutrient levels. Results indicated that the fresh watermelon seeds had moisture content in the range of $10.81-12.04 \%$; oxalate, $0.43-0.48 \mathrm{~g} / 100 \mathrm{~g}$ $\mathrm{db}$; phytate, $0.23-0.30 \mathrm{~g} / 100 \mathrm{~g} \mathrm{db}$ and tannin, 5.06-6.45 g/100g db. The boiling-oven drying and roasting significantly reduced the levels of the antinutrients. Decrease in the oxalate levels was in the range of $92-96 \%$ for boiled-oven dried samples and $49-64 \%$ for roasted samples. Decrease in the phytate levels ranged $58-76 \%$ and $73-82 \%$ for boiled-oven dried and roasted samples, respectively. However, decrease in the tannin levels ranged $15-35 \%$ for boiled-oven dried samples and $23-38 \%$ for roasted samples. The present findings suggest watermelon seeds contain antinutrients which are minor components and can be reduced by boiling and roasting of the seeds.
\end{abstract}

Volume 6 Issue 2 - 2018

\author{
Philip W Addo,' Jacob K Agbenorhevi,' David \\ Adu-Poku² \\ 'Department of Food science and Technology, Kwame Nkrumah \\ University of Science and Technology, Kumasi, Ghana \\ ${ }^{2}$ Department of Chemical Sciences, University of Energy and \\ Natural Resources, Sunyani, Ghana
}

\begin{abstract}
Correspondence: Jacob K Agbenorhevi, Department of Food science and Technology, Kwame Nkrumah University of Science and Technology, Kumasi, Ghana, Tel +233 208954223, Email
\end{abstract} jkagbenorhevi@yahoo.com,jkagbenorhevi.cos@knust.edu.gh

Received: July 20, 2016 | Published: April 27, 2018

Keywords: Citrullus lanatus, antinutrients, oxalate, phytate, tannin

\section{Introduction}

Watermelon, Citrullus lanatus, a tropical fruit crop is a herbaceous creeping plant belonging to the family cucurbitaceae. Watermelon grows in almost all parts of Africa and South East Asia. ${ }^{1}$ Watermelon is thought to have been domesticated in Africa at least 4000 years ago. ${ }^{2}$ There are over 1.3 million hectares of watermelons grown worldwide with China (68.9\%) and the middle-east countries being the world's largest producers. Other leading countries are Turkey (4.7\%), Iran (2.3\%), United States $(2.2 \%)$ and Egypt (1.7\%). Watermelon fruit is large, smooth, and varies from in shape ranging from round to cylindrical. The skin can be solid green or green striped with yellow. The edible pulp is usually pink with many flat, oval, black seeds throughout. Previous studies have shown watermelon seeds as considerable source of food for human nutrition and health. ${ }^{3-6}$

Watermelon varieties fall into 3 broad classes based on how the seeds were developed; open pollinated, hybrid and triploid or seedless.? They are also classified according to fruit shape, rind color or pattern, and size. Jubilee types of watermelon are oblong in shape with dark stripes on the light green background but are similar in shape and size to the Charleston gray types. There are also the Crimson Sweet types, All-sweet types, Royal Sweet or Mirage types and Small "icebox" watermelons. ${ }^{8}$ In Ghana, Black Diamond, Kaolack and Crimson sweet are the most common varieties.

The nutritional value and antinutrient content of watermelon seed have not been given much attention such that these seeds are often discarded while the fruit is eaten. ${ }^{69}$ A possible way of achieving nutrition security is through exploitation and utilization of available food sources and resources. As a result, the antinutrient factors must be determined to ensure human and animal nutrition security. Antinutritional factors have been described as substances that block or inhibit important metabolic pathways, especially digestion. These substances generally reduce the bioavailability of nutrients such as proteins, vitamins and minerals. The most common anti-nutritional factors include tannins, phytate and oxalate. ${ }^{10}$

Tannin is an astringent group of polyphenols of intermediate to high molecular weight that bind to and form complexes with proteins, minerals, digestive enzymes, and vitamins and inhibit their metabolism in the body. ${ }^{11}$ Phytic acid is the storage form of phosphate and inositol mostly in seeds and grains. Phytic acid is not digested by humans, hence is not a dietary source of inositol or phosphate. ${ }^{12}$ Phytates bind to minerals such as calcium, magnesium, iron, copper and zinc and inhibit their absorption by the small intestine..$^{13}$ Oxalate forms a complex with dietary calcium, thus rendering it unavailable for absorption and assimilation. It precipitates as insoluble salts accumulating in the renal glomeruli, and contributes to the development of renal disorder. ${ }^{14}$

Various methods for reducing the antinutrient composition in foods include soaking at high temperature, fermentation, extrusion, roasting, blanching and germination. ${ }^{15}$

The objective of this was to determine the level of antinutrients in three local watermelon varieties as influenced by boiling and roasting.

\section{Materials and methods}

\section{Materials and sample preparation}

The three varieties of watermelon fruits (namely; Sugar baby, Crimson sweet and Kaolack) were obtained from the Ada West District. The seeds were removed from each of the watermelon varieties and divided into three portions. A portion as control, the second portion was boiled at $100^{\circ} \mathrm{C}$ for $10 \mathrm{~min}$ and oven-dried at $50^{\circ} \mathrm{C}$ for $12 \mathrm{~h}$ and the last portion was roasted at $160^{\circ} \mathrm{C}$ for $30 \mathrm{~min}$. The processed seeds were milled for into flour using Double-M Germany Miller. ${ }^{16}$ All other chemicals used were of analytical grade. 


\section{Oxalate}

The oxalate content was measured using the titration method. ${ }^{17}$ All measurements were performed in triplicate.

\section{Phytate}

From each of the samples, $4 \mathrm{~g}$ was weighed into conical flasks. Hundred milliliters of $2 \% \mathrm{HCl}$ was added to digest the samples for 3 hours. Digested samples were filtered using a filter paper. The filtrates, Twenty-five milliliters of the filtrates were measured into $250 \mathrm{ml}$ conical flasks. A $5 \mathrm{~mL}$ volume of $0.3 \% \mathrm{NH}_{4} \mathrm{SCN}$ solution was added. The resulted mixtures were titrated against $0.1 \mathrm{M}$ ferrous chloride $\left(\mathrm{FeCl}_{3}\right)$ until a brownish-yellow colour end point that persisted for 5 min was obtained. The percentage phytate content was calculated as: Titre value $\mathrm{x} 0.1635 .{ }^{18}$ The determination was replicated three times and the average titre value was obtained.

\section{Tannin}

The tannin content was measured using the spectrophotometric method. ${ }^{19}$ The determination was replicated three times and the average value was reported.

\section{Statistical analysis}

The means and standard deviation of all replicates were calculated. Two-way analysis of variance (ANOVA) using Statistical Package for the Social Scientists was also performed on collected data. Tukey's (HSD) test at $\mathrm{p}<0.05$ was used.
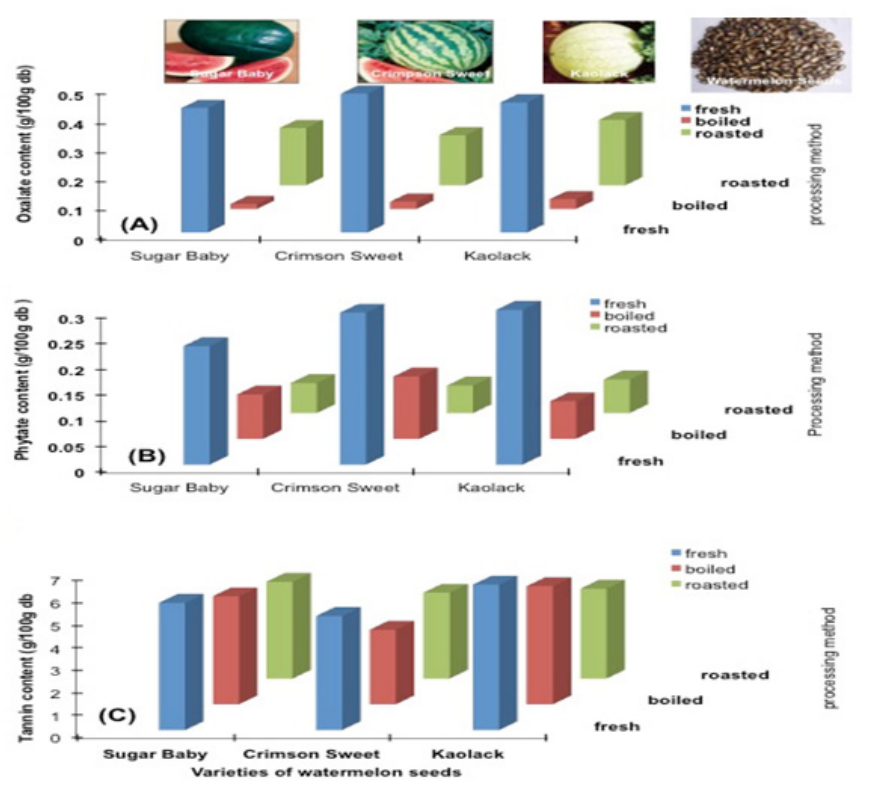

Figure I (A) Oxalate. (B) Phytate. (C) Tannin contents of fresh, boiled and roasted watermelon seeds.

\section{Results and discussion}

The watermelon seeds had moisture contents in the range of $12.04 \%-10.81 \%$ for fresh, $11.21 \%-9.65 \%$ for boiled and $8.29 \%-6.41 \%$ for roasted seeds. During roasting, there is evaporation of the free water in the seeds as a result of the high temperature employed. This process reduces the moisture content of the seeds. However, when watermelon seeds are boiled, there is an increase in the moisture content but for this study; the seeds were oven dried after the boiling. This caused a decrease in the moisture content. Boiling and the roasting treatment both decreased the moisture contents on the different varieties of the seeds significantly.

The primary risk factor for the formation of calcium oxalatecontaining kidney stones is hyperoxaluria. Increased dietary oxalate intake and/or intestinal absorption may provide the critical quantity of additional oxalate that triggers the formation of kidney stones. ${ }^{20}$ The oxalate levels of the fresh watermelon seeds had a range of $0.48 \mathrm{~g} / 100$ $\mathrm{g}$ dry matter (Crimson sweet) $-0.43 \mathrm{~g} / 100 \mathrm{~g}$ dry matter (Sugar baby). Most research articles suggested that most fruits contain only small quantities of oxalate while some such as kiwifruit and star fruit were reported to be moderately high. ${ }^{21}$

Phytates bind to iron and calcium in the body and could prevent their absorption into the body causing deficiencies. ${ }^{12}$ For this reason and because phytic acid is thought to have a positive dietary impact as an antioxidant to prevent carcinogenesis, determining the phytic acid content of foods is indispensable. The phytate levels had a range of $0.3 \mathrm{~g} / 100 \mathrm{~g}$ dry matter (Kaolack) $-0.23 \mathrm{~g} / 100 \mathrm{~g}$ dry matter (Sugar Baby).

Tannins are widespread in plants and particularly more in the fruits and cereal seeds. They are complex secondary metabolites having various medicinal properties but difficult to isolate in pure form. The mechanism of dietary effects may be understood by their ability to form complex with dietary proteins and may also inhibit the endogenous protein, such as digestive enzyme. ${ }^{22}$ The precise toxic amount of tannin to cause depression in human is not known. The tannin levels were calculated using the standard calibration curve and the values obtained had a range of $6.45 \mathrm{~g} / 100 \mathrm{~g}$ dry matter (Kaolack) $-5.06 \mathrm{~g} / 100 \mathrm{~g}$ dry matter (Crimson Sweet) for the fresh watermelon seeds. The findings are in good agreement with those reported by Olorode et al. ${ }^{23}$ with tannin level of $6.83 / 100 \mathrm{~g}$.

The oxalate levels decreased by $96.04 \%$ and $53.94 \%$ for boiled and roasted Sugar baby seeds respectively, $94.77 \%$ and $63.92 \%$ for boiled and roasted Crimson sweet seeds respectively and $92.5 \%$ and $49.79 \%$ for boiled and roasted Kaolack seeds respectively. The phytate levels decreased by $62.51 \%$ and $73.91 \%$ for boiled and roasted Sugar baby seeds respectively, $58.95 \%$ and $81.8 \%$ for boiled and roasted Crimson sweet seeds respectively and $75.67 \%$ and $78.28 \%$ for boiled and roasted Kaolack seeds respectively.

However, the tannin levels were affected by both varietal differences and the different processing methods. Plants which experience harsher conditions during their lifespan, according to research will produce more tannins than others of the same specie which experience relatively normal conditions. ${ }^{24}$ This leads to variation in the tannin levels of watermelon seeds. Tannin levels decreased by $15.09 \%$ and $23.85 \%$ for boiled and roasted Sugar baby seeds respectively, $34.54 \%$ and $24.59 \%$ for boiled and roasted Crimson sweet seeds respectively and $18.69 \%$ and $38.13 \%$ for boiled and roasted Kaolack seeds, respectively. Antinutrients are organic substances which are soluble in water. During the boiling process, a wet heat treatment method, most of the antinutrients leach out from the seeds as a result reducing their levels. Roasting is a dry heat treatment method, which employs the use of high temperatures. The high temperature used to roast the seeds lead to the destruction of the structures of the antinutrients. They were either converted into other forms or their active sites were destroyed. This resulted in the decrease in the level of antinutrients..$^{25,26}$ 


\section{Conclusion}

The findings suggest that watermelon seeds contain some antinutrients which could be reduced by boiling and roasting. However, boiling was more effective in reducing the levels of the antinutrients in the watermelon seeds.

\section{Acknowledgements}

None.

\section{Conflict of interest}

The author declares that there is none of the conflicts.

\section{References}

1. Koocheki A, Razavi SMA, Milani E, et al. Physical properties of watermelon seed as a function of moisture content and variety. Int Agrophysics. 2007;21(4):349-359.

2. Gichimu Bernard M, Owuor Barack O, Mwai Gideon N, et al. Morphological characterization of some wild and cultivated watermelon (Citrullus sp.) accessions in Kenya. Journal of Agricultural and Biological Science. 2009;4(2):1-9.

3. Guner N, Wehner TC. The genes of watermelon. Hort Science. 2004;39(6):1175-1182.

4. Inuwa HM, Aina VO, Gabi Baba, et al. Determination of Differences in Nutrient Composition of Citrullus vulgaries (Water Melon) Fruits after Plucking. British Journal of Dairy Sciences. 2011;2(2):27-30.

5. Inuwa HM, Aina VO, Baba Gabi, et al. Comparative determination of anti-nutritional factors in groundnut oil and palm oil. Advance Journal of Food Science and Technology. 2011;3(4):275-279.

6. Tabiri B, Agbenorhevi JK, Wireko-Manu FD, et al. Watermelon Seeds as Food: Nutrient Composition, Phytochemicals and Antioxidant Activity. International Journal of Nutrition and Food Sciences. 2016;5(2):139-144.

7. Lingli Lou. Inheritance of Fruit Characteristics in Watermelon Citrullus lanatus (Thunb). NCSU Libraries. 2009.

8. Boyhan George E, Granberry Darbie M, Kelley Terry W. Commercial Watermelon Production. The University of Georgia College of Agricultural and Environmental Sciences; 2000. p. 1-2.

9. Jayaprakasha GK, Singh RP, Sakariah KK. Antioxidant activity of grape seed (Vitis vinifera) extracts on peroxidation models in vitro. Food chemistry. 2001;73(3):285-290.

10. Kolawole Sunday E, Obueh Henrietta O. A study of the oxalate, phytate and cyanide contents of selected Nigerian foods and diet in Akwa Ibom and Cross River states of Nigeria. African Journal of Food Science and Technology. 2013;4(4):44-47.

11. Kumari M, Jain S. Tannins: An Antinutrient with Positive Effect to Manage Diabetes. Research Journal of Recent Sciences. 2012;1(12):70-73.

12. Phillippy BQ, Bland JM, Evens TJ. Ion Chromatography of Phytate in Roots and Tubers. J Agric Food Chem. 2012;51(2):350-353.
13. Ekholm P, Virkki L, Ylinen M, et al. The effect of phytic acid and some natural chelating agents on the solubility of mineral elements in oat bran. Food Chem. 2003;80(2):165-170.

14. Savage GP, Vanhanen I, Manson SM, et al. Effects of cooking on the soluble and insoluble oxalic acid content of some New Zealand foods. Journal of Food Composition and Analysis. 2000;13(3):201-206.

15. Njoki JW, Sila DN, Onyango AN. Impact of processing techniques on nutritional composition and antinutrient content of Grain amaranth: Food Science and Quality Management. International Institute for Science, Technology and Education Journals. 2014;25:1-8.

16. Kiin-Kabari DB, Akusu OM. Effect of processing on the proximate composition, functional properties and storage stability of water melon (Citrullus lanatus) seed flour. International Journal of Biotechnology and Food Science. 2014;2(7):143-148.

17. Ojinnaka MC, Ebinyasi CS, Ihemeje A, et al. Nutritional Evaluation of Complementary Food Gruels Formulated from Blends of Soybean Flour and Ginger Modified Cocoyam Starch. Advance Journal of Food Science and Technology. 2013;5(10):1325-1330.

18. Aina VO, Binta Sambo, Amina Zakari, et al. Determination of Nutritional and Antinutrient Content of Vitis vinifera (Grapes) Grown in Bomo (Area C) Zaria, Nigeria. Advance Journal of Food Science and Technology. 2013;4(6):445-448.

19. Vasundhara S, Garima M, Akash S, et al. A comparative study on quantitative estimation of tannins in terminalia, chebula, terminalia belerica, terminalia arjuna and saraca indica using spectrophotometer. Asian J Pharm Clin Res. 2013;6(Suppl 3):148-149.

20. Al-Wahsh Ismail A, Liebman Michael, Wu Yan. A comparison of two extraction methods for food oxalate assessment. Journal of Food Research. 2012;1(2):233-239.

21. Rassam M, Laing W. Variation in ascorbic acid and oxalate levels in the fruit of Actinidia Chinensis tissues and genotypes. Journal of Agricultural and Food Chemistry. 2005;53(6):2322-2326.

22. Shils ME, Shike M, Ross AC, et al. Modern nutrition in health and disease. Lippincott Williams and Wilkins, 10th ed. Wolters Klumer Company; 2006. p. $280-281$.

23. Olorode Omobolanle O, Idowu Michael A, Bamgbose Adefunke, et al. Chemical, phytochemical and functional properties of selected seeds' flours. International. Journal of Nutrition and Food Sciences. 2014;3(6):572-578.

24. Hassanpour Shahin, Maherisis Nasser, Eshratkhah Behrad, et al. Plants and secondary metabolities. Internataional Journal of Forest, Social and Erosion. 2011;254-261.

25. Olawepo KD, Banjo OT, Jimoh WA, et al. Effect of cooking and roasting on nutritional and anti-nutritional factors in Kenaf (Hibiscus cannabinus) seed meal. Food Science and Quality Management. 2014.

26. FAO Agricultural Production Statistics Database (FAOSTAT) (2008). 